\title{
Effects of Inhibitors of Protein, RNA and DNA Synthesis on Heat-injured Salmonella typhimurium LT2
}

\author{
By R. F. GOMEZ, K. D. BLAIS, A. HERRERO AND A. J. SINSKEY \\ Department of Nutrition and Food Science, Massachusetts Institute of Technology, \\ Cambridge, Massachusetts 02139, U.S.A.
}

(Received I March 1976)

SUMMARY

The role of protein, RNA and DNA synthesis in the repair of thermal injury in Salmonella typhimurium was investigated. Thermal injury was assessed by the 'minimal medium recovery' system: after heat treatment, higher viable counts are obtained on minimal-medium agar than on complex-medium agar, and the ability of heated bacteria to form colonies on complex-medium agar is recovered when they are incubated in liquid minimal medium. This recovery is inhibited by rifampin and chloramphenicol, but not by nalidixic acid. In addition, rifampin causes a loss in viability. Alkaline sedimentation analyses of radioactively labelled DNA showed that hydroxyurea and rifampin, unlike chloramphenicol and nalidixic acid, cause DNA breaks in heated bacteria. The results indicate that rifampin is lethal to heated bacteria and that chloramphenicol, though not lethal, prevents repair of thermal damage.

\section{INTRODUCTION}

We have previously reported (Gomez et al., I973) that, following heat treatment, Salmonella typhimurium LT2 shows a lower survival on complex-medium agar than on minimalmedium agar. This phenomenon, known as minimal medium recovery (MMR), is analogous to the results found in ultraviolet light irradiated $\mathrm{rec}^{-}$Escherichia coli (Ganesan \& Smith, I968). The toxic effect of complex media on heat-treated $S$. typhimurium is believed to be due to its ability to induce DNA breaks in heated bacteria (Gomez \& Sinskey, 1973). We have suggested that heat treatment causes a primary lesion in DNA or its metabolic and catabolic enzyme systems (Gomez \& Sinskey, 1973). Incubation in complex media converts this primary lesion into in vivo DNA breaks or alkali-labile bonds, and these events are accompanied by a loss of viability.

Differential plating on minimal versus complex medium can therefore be used as a measurement or indicator of thermal injury (Gomez et al., 1973). A repair process for this type of injury has been observed (Gomez \& Sinskey, 1973; Wilson \& Davies, 1976).

When heated cultures are incubated in liquid minimal medium, the viable counts on complex media increase until they are equal to those on minimal media. This repair process occurs in the absence of growth. In fact, exponential growth does not start until the viable counts on minimal medium and complex medium are the same, i.e. until the heat injury has been repaired. In addition, when repair has been completed, complex media no longer induce DNA breaks.

To study the mechanisms of thermal injury and repair, inhibitors have been used to probe the site of injury and to determine the metabolic requirements of repair. Iandolo \& Ordal (I966) reported that the recovery (regain of salt tolerance) of thermally injured Staphylococcus aureus was not inhibited or affected by penicillin, cycloserine, 2,4-dinitrophenol or 
chloramphenicol. However, actinomycin D completely inhibited repair. Likewise, Tomlins \& Ordal (197I) showed that rifamycin, an inhibitor of RNA synthesis, blocked repair of $S$. typhimurium after heat treatment. With $S$. typhimurium, ATP and protein synthesis were also required for repair, as determined by the inhibitory effects of 2,4-dinitrophenol and chloramphenicol.

In this paper, we report the effect of inhibitors of protein, RNA, and DNA synthesis on MMR of heated $S$. typhimurium LT2, and their relationship to DNA breaks.

\section{METHODS}

Bacteria. Strain DB2 I, derived from S. typhimurium LT2 and cured of known prophages (Botstein, I968), was provided by D. Botstein of the Department of Biology, Massachusetts Institute of Technology, and used throughout these studies.

Media, culture and enumeration procedures. Salmonella typhimurium DB2 I was grown at $37^{\circ} \mathrm{C}$ to the exponential phase in a glucose/mineral-salts medium (M-9; Gomez et al., 1973), to a density of $1.0 \times 10^{8}$ to $3.0 \times 10^{8}$ viable bacteria $\mathrm{ml}^{-1}$. All cultures were shaken ( 50 rev. $\mathrm{min}^{-1}$ ) in $250 \mathrm{ml}$ Erlenmeyer flasks.

For radioactive labelling, M-9 medium contained (per $\mathrm{ml}$ ) $250 \mu \mathrm{g} 2^{\prime}$-deoxyadenosine (Boyce \& Setlow, I962) and either 5 to $10 \mu \mathrm{Ci}\left[\right.$ methyl $\left.{ }^{3} \mathrm{H}\right]$ thymidine $\left(6.7 \mathrm{Ci} \mathrm{mM}{ }^{-1}\right.$, New England Nuclear) or $5 \mu \mathrm{Ci}\left[\right.$ methyl $\left.{ }^{14} \mathrm{C}\right]$ thymidine $\left(5 \mathrm{I} \cdot 5 \mathrm{mCi} \mathrm{m}^{-1}\right.$, New England Nuclear). The labelled bacteria were harvested by centrifuging $\left(4150 \mathrm{~g}\right.$ ) for $5 \mathrm{~min}$ at $37^{\circ} \mathrm{C}$, washed once, centrifuged again, and resuspended in M-9 medium containing (per ml) $20 \mu \mathrm{g}$ nonradioactive thymidine and $250 \mu \mathrm{g} 2^{\prime}$-deoxyadenosine. The bacteria were incubated for 30 $\min$ at $37^{\circ} \mathrm{C}$ to chase the intracellular radioactivity into polymeric DNA.

Both unlabelled and labelled bacteria were harvested by centrifuging, washed, and resuspended in distilled water at $37^{\circ} \mathrm{C}$, to a final concentration of $3 \times 10^{8}$ to $9 \times 10^{8}$ viable bacteria $\mathrm{ml}^{-1}$.

Viability was determined by spreading the surface of agar plates with $0.1 \mathrm{ml}$ of appropriate dilutions in $0.067 \mathrm{M}$-sodium phosphate buffer $\left(\mathrm{pH}_{7} \cdot 0\right)$. The media used for enumeration were M-9 and TSY [trypticase soy agar (BBL) enriched with $0.5 \%$ yeast extract (Difco)]. TSY and M-9 plates were incubated at $37^{\circ} \mathrm{C}$ for 24 and $48 \mathrm{~h}$, respectively, and visible colonies were counted.

Heat treatment. The ${ }^{3} \mathrm{H}$-labelled and unlabelled $S$. typhimurium LT2 were heated to $50{ }^{\circ} \mathrm{C}$ for $15 \mathrm{~min}$. Control cultures were held at $37^{\circ} \mathrm{C}$ for $15 \mathrm{~min}$.

Post-heat treatment of unlabelled bacteria. Portions ( $19 \mathrm{ml}$ ) of $\mathrm{M}-9$ medium, with or without metabolic inhibitors, were inoculated with heat-treated bacterial suspension (I $\mathrm{ml}$ ) and incubated at $37^{\circ} \mathrm{C}$. At various times during incubation, the number of viable bacteria was determined. Metabolic inhibitors were used at the following concentrations: chloramphenicol (Sigma), I00 $\mu \mathrm{g} \mathrm{ml}^{\mathbf{- 1}}$; hydroxyurea (Sigma), 0.I M; rifampin (Calbiochem), 40 $\mu \mathrm{g} \mathrm{ml}^{-1}$; nalidixic acid (Sigma), $20 \mu \mathrm{g} \mathrm{ml}^{-1}$. To remove the inhibitors, $3 \mathrm{ml}$ samples were filtered through Millipore membranes (HA $0.45 \mu \mathrm{m} ; 24 \mathrm{~mm}$ diam.), washed twice with $5 \mathrm{ml} 0.067 \mathrm{M}$-phosphate buffer $\left(\mathrm{pH} 7^{\circ} \mathrm{O}\right)$ and resuspended in $3 \mathrm{ml}$ phosphate buffer.

Post-heat treatment of labelled bacteria. Portions (19 ml) of M-9 medium, with or without metabolic inhibitors at the concentrations listed above, were inoculated with heat-treated ${ }^{3} \mathrm{H}$-labelled bacterial suspension (I ml) and incubated at $37{ }^{\circ} \mathrm{C}$. After $\mathrm{I} 5 \mathrm{~min}$, the bacteria were harvested by centrifuging and resuspended in $\mathrm{I} \mathrm{ml}$ distilled water. These suspensions were then subjected to alkaline sedimentation analysis.

In a different experiment, portions ( $\mathrm{I} 0 \mathrm{ml}$ ) of $\mathrm{M}-9$ medium containing chloramphenicol 


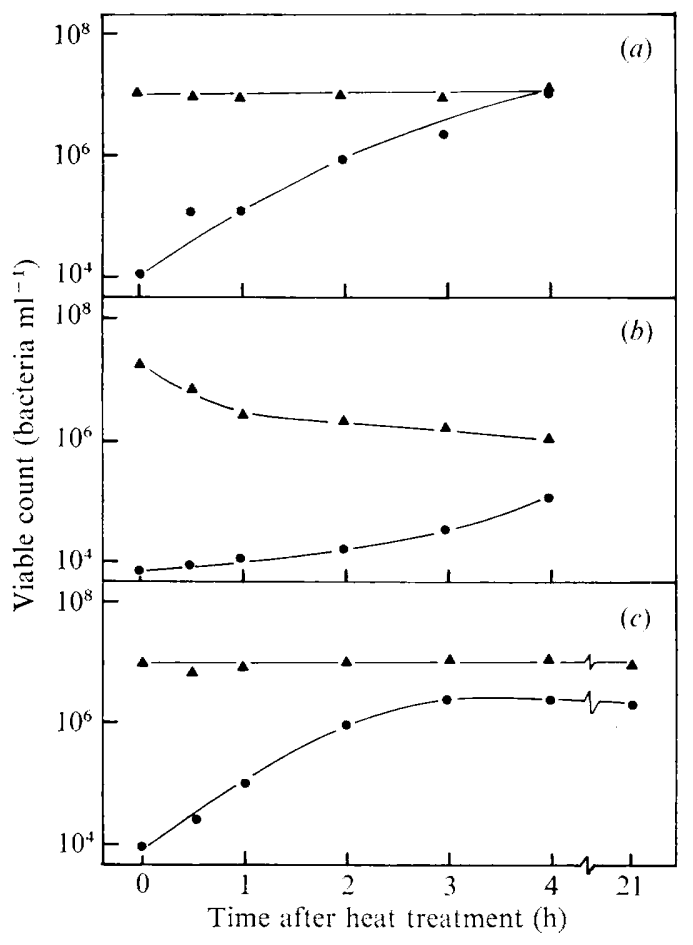

Fig. I. Post-heat treatment incubation in M-9 medium with inhibitors. Bacteria in water were held at $50^{\circ} \mathrm{C}$ for $15 \mathrm{~min}$. The culture was then diluted $(\mathrm{I}: 20)$ into $\mathrm{M}-9$ medium at $37^{\circ} \mathrm{C}$ containing: (a) nalidixic acid, $20 \mu \mathrm{g} \mathrm{ml}^{-1}$; (b) rifampin, $40 \mu \mathrm{g} \mathrm{ml}^{-1}$; (c) chloramphenicol, 100 $\mu \mathrm{g} \mathrm{ml}^{-1}$. At various times, the cultures were plated on M-9 agar ( $\boldsymbol{A})$ and TSY agar (O).

(I00 $\mu \mathrm{g} \mathrm{ml}^{-1}$ ) were inoculated with heat-treated ${ }^{3} \mathrm{H}$-labelled bacterial suspension ( $\mathrm{I} \mathrm{ml}$ ). After different times of incubation at $37^{\circ} \mathrm{C}$, $10 \mathrm{ml}$ double-strength TSY broth was added and the cultures were incubated for a further $15 \mathrm{~min}$ at $37^{\circ} \mathrm{C}$. The bacteria were harvested and resuspended in distilled water, as described in the previous section. The bacterial suspensions were subjected to alkaline sedimentation analysis.

Alkaline sedimentation analyses. These procedures have been described previously (Gomez $\&$ Sinskey, 1973). The amount of bacteria deposited on each gradient ranged from $3 \times 10^{7}$ to $9 \times 10^{7}$, giving an estimated 0.5 to $\mathrm{I} \cdot 5 \mu \mathrm{g}$ DNA per gradient. A value of $\mathrm{I} \cdot 6 \times 10^{-8} \mu \mathrm{g}$ DNA/cell was adopted (Davies \& Sinskey, 1973).

\section{RESULTS}

\section{Effect of metabolic inhibitors on minimal medium recovery}

Nalidixic acid (NA) did not inhibit repair of thermal injury (Fig. $1 a$ ). When rifampin (RIF) was incorporated into M-9 medium (Fig. $\mathrm{I} b$ ), the M-9 plate counts decreased and the TSY plate counts increased and approached the M-9 plate counts. Thus there was loss of viability and some bacteria underwent repair. In fact, in the presence of RIF the viability of heated bacteria decreased by more than $90 \%$.

Chloramphenicol (CAP) did not affect the viability of heated bacteria (Fig. I $c$ ). The TSY plate counts increased following incubation in liquid medium, but did not reach the same 


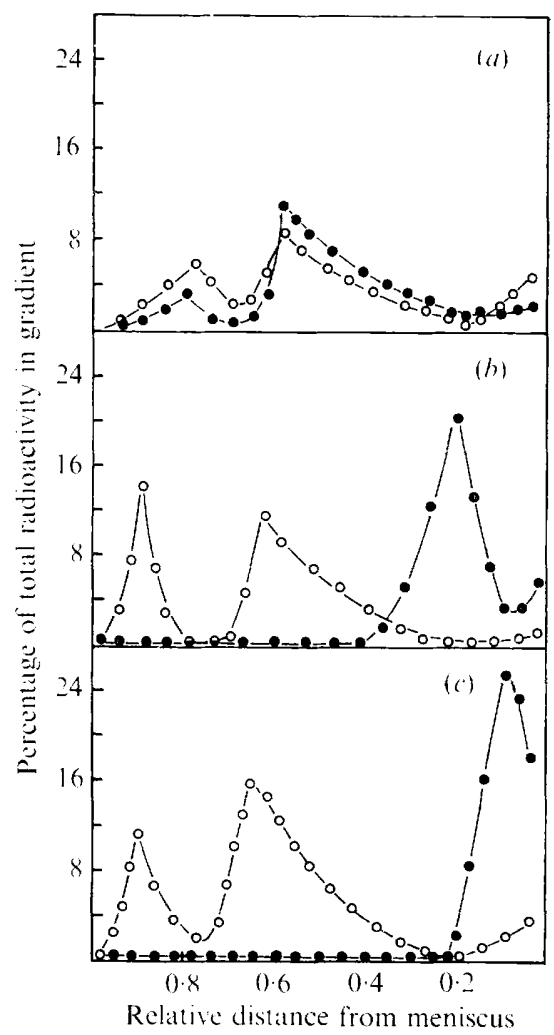

Fig. 2

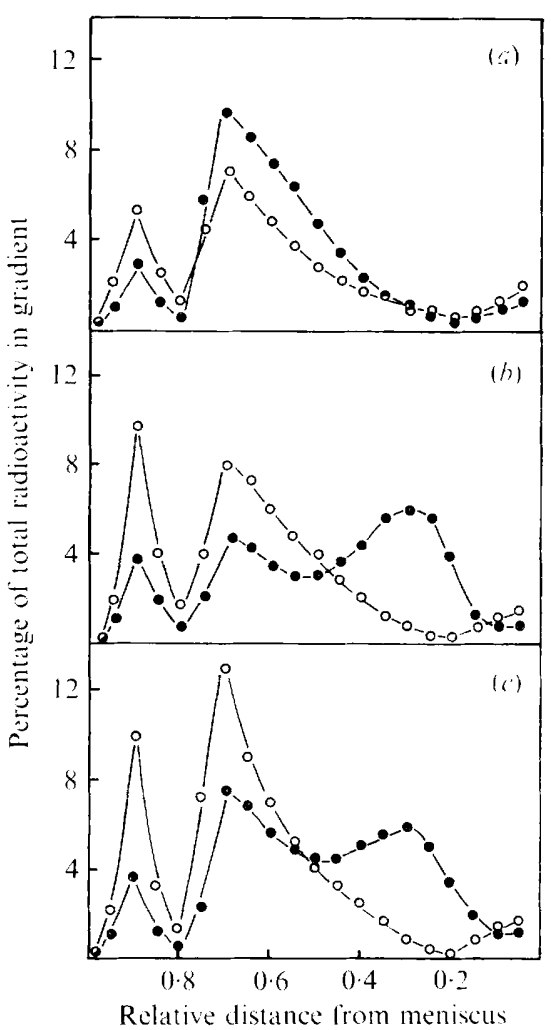

Fig. 3

Fig. 2. Alkaline sedimentation of ${ }^{3} \mathrm{H}$-labelled DNA ( ) from bacteria incubated in $\mathrm{M}-9$ medium containing $0.1 \mathrm{M}$-hydroxyurea $(\mathrm{M}-9 / \mathrm{HU})$. (a) Control bacteria (not exposed to $50^{\circ} \mathrm{C}$ ) incubated in $\mathrm{M}-9 / \mathrm{HU}$ for $15 \mathrm{~min}$ at $37^{\circ} \mathrm{C}$. (b) Heated bacteria (exposed to $50{ }^{\circ} \mathrm{C}$ for $15 \mathrm{~min}$ ) incubated in $\mathrm{M}-9$ / $\mathrm{HU}$ for $15 \mathrm{~min}$ at $37^{\circ} \mathrm{C}$. (c) Heated bacteria (exposed to $50^{\circ} \mathrm{C}$ for $15 \mathrm{~min}$ ) incubated in $\mathrm{M}-9 / \mathrm{HU}$ for $240 \mathrm{~min}$ at $37^{\circ} \mathrm{C}$. All gradients contained ${ }^{14} \mathrm{C}$-labelled DNA (O) from bacteria which were neither heated nor incubated in $\mathrm{M}-9 / \mathrm{HU}$.

Fig. 3. Alkaline sedimentation of ${ }^{3} \mathrm{H}$-labelled DNA ( ) from bacteria incubated in $\mathrm{M}-9$ medium containing rifampin $\left(40 \mu \mathrm{g} \mathrm{ml}^{-1}\right)$ (M-9/RIF). (a) Control bacteria (not exposed to $50{ }^{\circ} \mathrm{C}$ ) incubated in M-9/RIF for $15 \mathrm{~min}$ at $37^{\circ} \mathrm{C}$. (b) Heated bacteria (exposed to $50^{\circ} \mathrm{C}$ for $15 \mathrm{~min}$ ) incubated in M-9/RIF for 15 min at $37^{\circ} \mathrm{C}$. (c) Heated bacteria (exposed to $50^{\circ} \mathrm{C}$ for 15 min) incubated in M-9/ RIF for $240 \mathrm{~min}$ at $37^{\circ} \mathrm{C}$. All gradients contained ${ }^{14} \mathrm{C}$-labelled DNA $(O)$ as in Fig. 2 legend.

value as the M-9 plate counts. The difference between the M-9 and TSY plate counts was still evident after $2 \mathrm{I} \mathrm{h}$. This could reflect inhibition of repair of most of the bacteria.

\section{Effect of inhibitors on DNA molecular weight}

Previously (Gomez \& Sinskey, 1973) we showed that incubation in M-9 medium does not affect the DNA weight-average molecular weight of heated bacteria. However, DNA molecular weight was reduced when hydroxyurea (HU) or RIF was incorporated into M-9 medium (Figs $2 b$ and $3 b$ ). In the presence of $\mathrm{HU}$, the reduction of DNA molecular weight was still evident after $4 \mathrm{~h}$ incubation (Fig. $2 c$ ), indicating that DNA breaks caused by $\mathrm{HU}$ were not repaired. After $4 \mathrm{~h}$, there appeared to be a slight repair of the DNA breaks caused by RIF, but this was not always observed and we do not consider the amount of repair was 


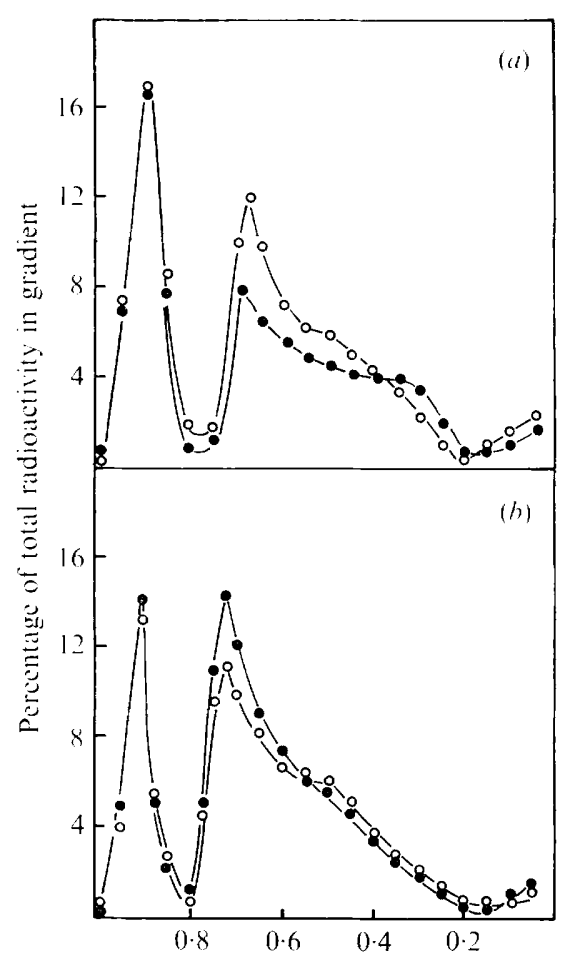

Relative distance from meniscus

Fig. 4

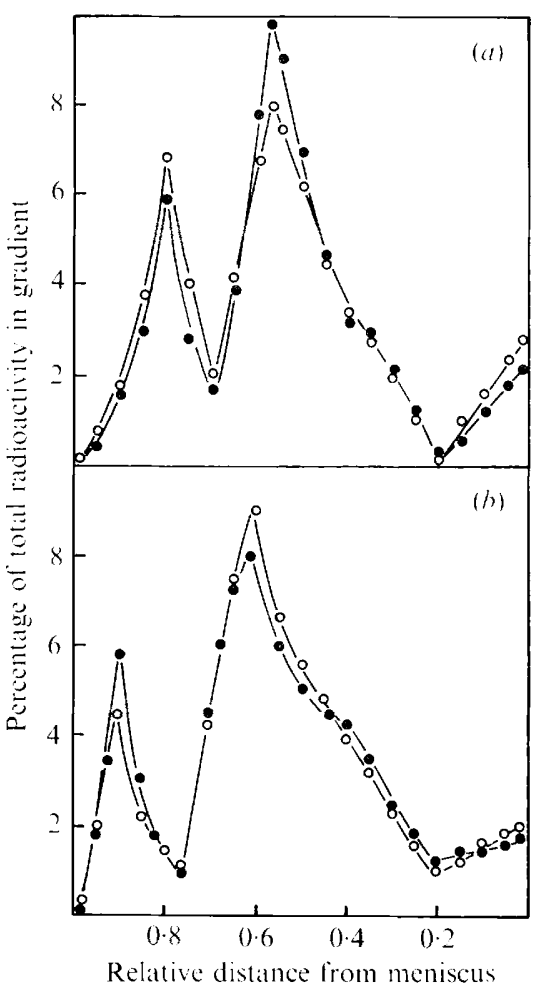

Fig. 5

Fig. 4. Alkaline sedimentation of ${ }^{3} \mathrm{H}$-labelled DNA ( ) from bacteria incubated in M-9 medium containing nalidixic acid $\left(20 \mu \mathrm{g} \mathrm{ml}^{-1}\right)$ (M-9/NA). (a) Control bacteria (not exposed to $50^{\circ} \mathrm{C}$ ) incubated in M-9/NA for $15 \mathrm{~min}$ at $37^{\circ} \mathrm{C}$. (b) Heated bacteria (exposed to $50^{\circ} \mathrm{C}$ for $15 \mathrm{~min}$ ) incubated in M-9/NA for 15 min at $37^{\circ} \mathrm{C}$. All gradients contained ${ }^{14} \mathrm{C}$-labelled DNA (O) as in Fig. 2 legend.

Fig. 5. Alkaline sedimentation of ${ }^{3} \mathrm{H}$-labelled DNA (O) from bacteria incubated in $\mathrm{M}-9$ medium containing chloramphenicol (I00 $\mu \mathrm{g} \mathrm{ml}^{-1}$ ) (M-9/CAP). (a) Control bacteria (not exposed to $50^{\circ} \mathrm{C}$ ) incubated in M-9/CAP for $15 \mathrm{~min}$ at $37^{\circ} \mathrm{C}$. (b) Heated bacteria (exposed to $50{ }^{\circ} \mathrm{C}$ for $15 \mathrm{~min}$ ) incubated in M-9/CAP for 15 min at $37^{\circ} \mathrm{C}$. All gradients contained ${ }^{14} \mathrm{C}$-labelled DNA (O) as in Fig. 2 legend.

significant. The DNA molecular weight of control bacteria (not heated) was not affected by either HU or RIF (Figs $2 a$ and $3 a$ ).

Incubation of heated bacteria in M-9 medium containing NA or CAP (Figs $4 b$ and $5 b$ ) did not affect the DNA sedimentation patterns. This was expected since neither CAP nor NA affected the viability of heated bacteria.

\section{DNA degradation}

The conversion of acid-insoluble radioactivity to acid-soluble material during the various treatments can be estimated from Table $I$. The amounts of radioactivity recovered from each set of gradients (e.g. Fig. 2 compared with Fig. 5) varied because different initial concentrations of $\left[{ }^{3} \mathrm{H}\right]$ thymidine were used in each experiment. The values for Figs $2 b, 3 b$, $4 b$ and $5 b$, which correspond to I 5 min exposures of heated cells to the different inhibitors, indicate that little or no DNA solubilization occurred. These amounts of solubilization are 


\section{Table I. Radioactivity recovered from alkaline sedimentation gradients}

Solubilization in heated bacteria is expressed as a percentage of the solubilization in control bacteria.

\section{Treatment}

Fig. $2(a)$

$2(b)$

$2(c)$

Fig. $3(a)$

$3(b)$

$3(c)$

Fig. $4(a)$

$4(b)$

Fig. $5(a)$

$5(b)$

$$
10^{-4} \times{ }^{3} \mathrm{H} \text {-radioactivity (c.p.m.) }
$$

$9 \cdot 67$

$9 \cdot 75$

$7 \cdot 77$

I $2 \cdot 45$

$12 \cdot 03$

$9 \cdot 92$

$12 \cdot 42$

$12 \cdot 32$

$6 \cdot 04$

$5 \cdot 8 I$
Solubilization $(\%)$

0
0
$19 \cdot 7$
0
$3 \cdot 4$
20.3
0
0.8
0
3.8

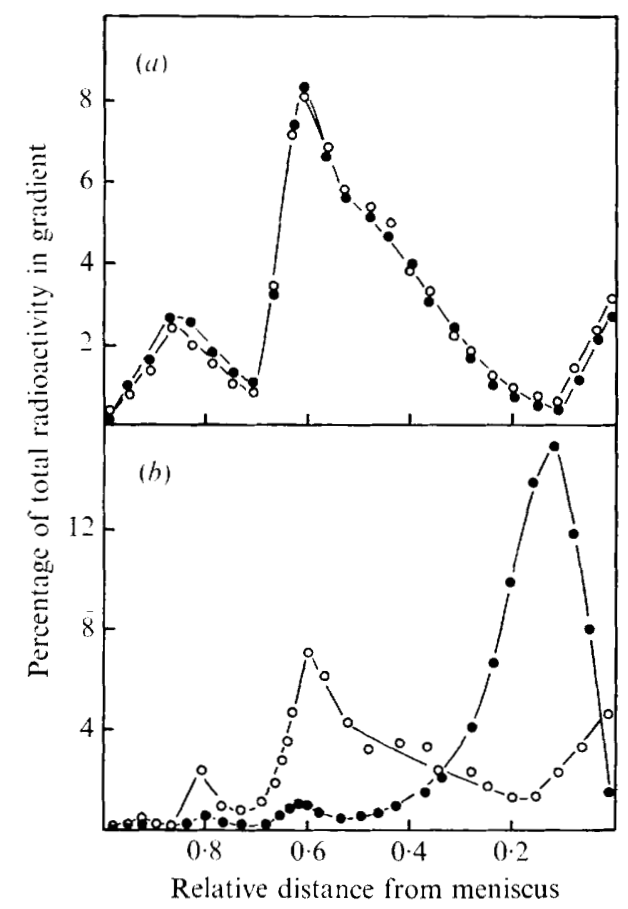

Fig. 6. Alklaine sedimentation of ${ }^{3} \mathrm{H}$-labelled DNA (O) from bacteria incubated in $\mathrm{M}-9$ medium with or without chloramphenicol (100 $\mu \mathrm{g} \mathrm{ml}^{-1}$ ) (M-9/CAP) and shifted to TSY. (a) Heated bacteria (exposed to $50^{\circ} \mathrm{C}$ for $15 \mathrm{~min}$ ) incubated in M-9 for $300 \mathrm{~min}$ at $37^{\circ} \mathrm{C}$ and then shifted to TSY for $15 \mathrm{~min}$ at $37^{\circ} \mathrm{C}$. (b) Heated bacteria (exposed to $50^{\circ} \mathrm{C}$ for $15 \mathrm{~min}$ ) incubated in M-9/CAP for $300 \mathrm{~min}$ at $37^{\circ} \mathrm{C}$ and then shifted to TSY for $15 \mathrm{~min}$ at $37^{\circ} \mathrm{C}$. All gradients contained ${ }^{14} \mathrm{C}$ labelled DNA (O) as in Fig. 2 legend.

not enough to account for the reduction in molecular weight observed in Figs $2 b$ and $3 b$. Thus, the original molecular-weight reductions must be due to internal DNA scissions rather than to massive exonucleolytic activity. After $4 \mathrm{~h}$ exposure of heated bacteria to $\mathrm{HU}$ (Fig. 2 c) and RIF (Fig. $3 c$ ), $19.7 \%$ and $20.3 \%$, respectively, of acid-insoluble $\left[{ }^{3} \mathrm{H}\right]$ thymidine had been lost. During this period there was little or no repair of DNA breaks. 


\section{Effect of CAP on the sensitivity of heated bacteria to TSY-induced DNA breaks}

One way of establishing the degree of repair of thermal injury is to determine the extent to which DNA in heated bacteria is sensitive to TSY-induced breaks (Gomez \& Sinskey, 1973). If bacteria are exposed to TSY broth immediately after heat treatment, their DNA molecular weight is reduced. However, when bacteria are incubated in M-9 before shifting to TSY, the reduction of DNA molecular weight is less, and is eliminated after $5 \mathrm{~h}$ incubation in M-9 medium.

This offered a means of testing the significance of the inhibitory effect of CAP on the repair of thermal injury (Fig. I $c$ ). When heated bacteria were incubated in M-9 containing CAP ( $100 \mu \mathrm{g} \mathrm{ml}^{-1}$ ) for $300 \mathrm{~min}$ and then shifted to TSY, the reduction of DNA molecular weight still occurred (Fig. 6 b). This is in sharp contrast to the results for bacteria incubated in M-9 medium without CAP (Fig. 6a).

DNA solubilization cannot be estimated in Fig. 6 because the experiments were performed with bacterial suspensions that had been labelled with different concentrations of $\left[{ }^{3} \mathrm{H}\right]$ thymidine. However, prolonged incubation of heated bacteria in M-9/CAP results in approximately $4 \%$ solubilization with no observable DNA molecular-weight reduction (unpublished results). We have previously reported (Gomez \& Sinskey, 1973) that incubation of heat-damaged bacteria in TSY for 15 min causes negligible DNA degradation. Therefore, we doubt that the molecular-weight reduction observed in Fig. $6 b$ is due to exonucleolytic activity.

\section{DISCUSSION}

The effect of RIF on the viability of heated bacteria is similar to that previously observed for HU and TSY (Gomez et al., 1973). Exposure of heated bacteria to RIF causes loss in viability. In addition, both RIF and HU, as well as TSY (Gomez \& Sinskey, I973), cause a reduction in molecular weight.

Why do RIF and HU induce DNA breaks and loss of viability? RNA is degraded during heat treatment and resynthesized during repair in $S$. typhimurium (Tomlins \& Ordal, I97I). We also know that endonuclease $\mathrm{I}$ is competitively inhibited by RNA in vitro (Goebel \& Helinski, I970). Thus, it is possible that inhibition of RNA synthesis by rifampin (Wehrli \& Staehelin, I97 I) may result in the activation of endonuclease I. The possibility that rifampin acts by inhibiting a repair process involving RNA synthesis cannot be discarded. However, the hypothesized inhibition would automatically result in DNA strand breakage and cell inactivation.

HU has been reported to act by inhibiting the ribonucleotide diphosphate reductase system, thus depleting the cell of DNA precursors (Krakoff, Brown \& Reichard, 1968). Sinha \& Snustad (1972) found that HU did not induce detectable single- or double-strand breaks in the DNA of $E$. coli. Thus our finding that HU induces DNA strand breaks in heated bacteria, leads us to believe that the repair of thermal damage, or at least maintenance of viability, requires DNA synthesis. However, the NA experiments show that inhibition of DNA synthesis per se is not enough to cause DNA breakage in heated bacteria. NA permitted repair of injured cells and did not cause any DNA strand breakage, although it is known to inhibit semiconservative DNA replication (Bourguignon, Levitt \& Sternglanz, I973). Thus, the lethal effect of $\mathrm{HU}$ on heated bacteria appears to be due to the inhibition of precursors of DNA synthesis involved in repair. However, DNA synthesis during repair of thermal injury has not been demonstrated by the classical techniques of $\left[{ }^{3} \mathrm{H}\right]$ thymidine uptake into heated bacteria (Tomlins \& Ordal, 197I). 
The small amounts of DNA degradation during the 15 min treatments strengthen our argument that the observed reduction in DNA molecular weight is due to DNA strand breakage rather than to massive exonucleolytic activity.

Inhibition of the repair of approximately $80 \%$ of the heated bacteria by CAP indicates a requirement for protein synthesis during repair. However, some bacteria can repair in the presence of CAP. Analysis of these results suggests three possibilities. (i) There is a distribution of damaged cells in which most $(80 \%)$ require de novo protein synthesis to replace heat-inactivated enzymes required for repair; but in some $(20 \%)$, the proteins required for repair were not lost during heating. (ii) There are two distinct types of damage, one which requires protein synthesis for repair and one which does not. Thus, in some cells, only a type of damage which can be repaired in the presence of CAP occurred. There is evidence that systems involved in the repair of ultraviolet light lesions can be of two types: growthmedium dependent (sensitive to CAP) and independent (insensitive to CAP) (Ganesan \& Smith, I972; Youngs, Van der Schueren \& Smith, 1974). (iii) CAP does not penetrate, or does not act, until some bacteria have repaired.

The appearance of anomalously sedimenting DNA in all control profiles has been observed previously (Davies, Sinskey \& Botstein, I973; Gomez \& Sinskey, I973). The nature and biological significance, if any, of DNA sedimenting close to the bottom of the gradient has not been elucidated. Control experiments (not shown) demonstrated that this material was not dependent on the amount of bacteria deposited on the gradients. We have decreased, at discrete intervals, the amount of bacteria on the gradients, reducing the DNA concentration to a value 500 times smaller than that used in these experiments. To achieve the necessary specific activity of radioactivity in DNA, the amount of $\left[\right.$ methyl $\left.{ }^{3} \mathrm{H}\right]$ thymidine in the growth medium was increased to $200 \mu \mathrm{Ci} \mathrm{ml}^{-1}$. The amount of DNA from control bacteria found to the left of the main peak was not affected by the dilution: it ranged from $\mathrm{I} 5$ to $30 \%$, with a mean value of $24 \%$ and a standard deviation of $6 \%$. Throughout the range of cell dilutions there was no obvious trend to increase or decrease the amount of DNA to the eft of the main peak, although the resolution in this area did increase so that two peaks were observed. Regardless of the nature and biological significance of this DNA, it in no way detracts from the qualitative aspects of our work. It should also be noted, without further speculation, that heated bacteria, treated with HU (Fig. 2) or TSY (Fig. 6) do not yield sedimentation profiles with fast-sedimenting DNA.

In conclusion, RIF, like HU (Gomez et al., I973), is toxic to heated cells. The functions which these compounds reportedly block, RNA synthesis by RIF (Wehrli \& Staehelin, I97I) and DNA synthesis by HU (Krakoff et al., I968), are required to maintain viability and DNA integrity after heat treatment. CAP or protein synthesis inhibition is not lethal to heated bacteria, but prevents the repair of heat damage in most of them.

This investigation was supported by grants 2-POI-ESo0597 from the National Institute of Environmental Health Sciences and FD-00530 from the Food and Drug Administration, and is contribution no. $267 \mathrm{r}$ from the Department of Nutrition and Food Science, Massachusetts Institute of Technology. 


\section{REFERENCES}

Botstein, D. (1968). Synthesis and maturation of phage P22 DNA. I. Identification of intermediates. Journal of Molecular Biology 34, 62 I-64I.

Bourguignon, G. J., Levitt, M. \& Sternglanz, R. (1973). Studies on the mechanism of action of nalidixic acid. Antimicrobial Agents and Chemotherapy 4, 479-486.

Boyce, R. P. \& Setlow, R. B. (1962). A simple method of increasing the incorporation of thymidine into the deoxyribonucleic acid of Escherichia coli. Biochimica et biophysica acta 16, 6r8-620.

DAviES, R. \& Sinskey, A. J. (1973). Radiation-resistant mutants of Salmonella typhimurium LT2: development and characterization. Journal of Bacteriology I13, I33-I44.

Davies, R., Sinskey, A. \& Botstein, D. (1973). Deoxyribonucleic acid repair in a highly radiation-resistant strain of Salmonella typhimurium. Journal of Bacteriology 114, 357-366.

Ganesan, A. K. \& Smith, K. C. (1968). Recovery of recombination deficient mutants of Escherichia coli K I 2 from ultraviolet irradiation. Cold Spring Harbor Symposia on Quantitative Biology 33, 235-242.

GANESAN, A. K. \& SMITH, K. C. (1972). Requirement for protein synthesis in rec-dependent repair of deoxyribonucleic acid in Escherichia coli after ultraviolet or X-irradiation. Journal of Bacteriology II, 575-585.

Goebel, W. \& HelinSKI, D. R. (1970). Nicking activity of an endonuclease-I-transfer ribonucleic acid complex of Escherichia coli. Biochemistry, New York 9, 4793-480I.

Gomez, R. F. \& Sinskey, A. J. (1973). Deoxyribonucleic acid breaks in heated Salmonella typhimurium LT2 after exposure to nutritionally complex media. Journal of Bacteriology 115, 522-528.

Gomez, R. F., Sinskey, A. J., Davies, R. \& Labuza, T. P. (1973). Minimal medium recovery of heated Salmonella typhimurium LT2. Journal of General Microbiology 74, 267-274.

IANDOLO, J. J. \& ORDAL, Z. J. (I966). Repair of thermal injury of Staphylococcus aureus. Journal of Bacteriology 9r, 134-I 42.

Krakoff, I. H., Brown, N. C. \& Reichard, P. (1968). Inhibition of ribonucleoside diphosphate reductase by hydroxyurea. Cancer Research 28, $1559-1565$.

Sinha, N. K. \& Snustad, D. P. (I972). Mechanism of inhibition of deoxyribonucleic acid synthesis in Escherichia coli by hydroxyurea. Journal of Bacteriology 112, I32 I-I 334.

Tombins, R. I. \& ORDal, Z. J. (I97I). Requirements of Salmonella typhimurium for recovery from thermal injury. Journal of Bacteriology ro5, $512-518$.

WILsON, J. M. \& DAVIEs, R. (1976). Minimal medium recovery of thermally injured Salmonella senftenberg 4969. Journal of Applied Bacteriology 40, 365-374.

Wehrli, W. \& Staehelin, M. (I971). Actions of the rifamycins. Bacteriological Reviews 35, $290-309$.

Youngs, D. A., VAN DER Schueren, E. \& SMITH, K. C. (I974). Separate branches of the $u v r^{-}$gene dependent excision repair process in ultraviolet-irradiated Eschericia coli $\mathrm{K} 12$ cells; their dependence upon growth medium and the polA, recA, recB, and exrA genes. Journal of Bacteriology 117, 717-725. 